\title{
THE REGIONAL DIFFERENCES OF GPP ESTIMATION BY SOLAR INDUCED FLUORESCENCE
}

\author{
X. Wang ${ }^{1}$, S. Lu ${ }^{1, *}$ \\ ${ }^{1}$ School of Geographical Science, Northeast Normal University, Changchun 130024, China - (wangx203, lus123)@ nenu.edu.cn
}

\section{Commission III, WG III/10}

KEY WORDS: Gross primary productivity, Solar-induced chlorophyll fluorescence, Temperature, Precipitation, Simple linear regression analysis, Determination coefficient

\begin{abstract}
: research.

\section{INTRODUCTION}

Gross primary productivity (GPP) is the total biomass from sunlight energy to chemical energy through photosynthesis of plants. On the ecosystem scale, a spatially and temporally clear estimate of GPP can provide important information about when where and how much carbon dioxide is absorbed in the land carbon budget (Parazoo et al. 2014;Zhang et al. 2014). Estimating GPP are usually based on models and algorithms with ground observation and remote sensing data sets(Heinsch et al. 2006). However, previous estimation methods have seldom been related to plant photosynthetic functioning.
\end{abstract}

Estimating gross primary productivity (GPP) at large spatial scales is important for studying the global carbon cycle and global climate change. In this study, the relationship between solar-induced chlorophyll fluorescence (SIF) and GPP is analysed in different levels of annual average temperature and annual total precipitation respectively using simple linear regression analysis. The results showed high correlation between SIF and GPP, when the area satisfied annual average temperature in the range of $-5^{\circ} \mathrm{C}$ $\sim 15^{\circ} \mathrm{C}$ and the annual total precipitation is higher than $200 \mathrm{~mm}$. These results can provide a basis for future estimation of GPP

Solar-induced chlorophyll fluorescence (SIF) is an electromagnetic signal emitted by vegetation chlorophyll in red and near-infrared regions in response to the absorption of photosynthetically active radiation. The two emission peaks of SIF is $685-690 \mathrm{~nm}$ and $730-740 \mathrm{~nm}$, respectively(Sun et al. 2017). With the development of spectroscopy, we can obtain the space-based monitoring of SIF that makes possible to realize rapid and global estimation of GPP. Recently, a number of studies have shown that remote measurement of SIF can estimate GPP well at the largely scale (Damm et al. 2010; Frankenberg et al. 2011b;Joiner et al. 2012).

It should be noted that the SIF-GPP relationship is not suitable for all conditions (Frankenberg et al. 2011a), however, few people take integratedly environmental factors into account to estimate GPP with SIF. In this study, our primary goal is to find the best environmental conditions of estimating GPP with satellite-level SIF in China.

\section{DATA AND ANALYSIS}

\subsection{GOME-2 SIF}

This study used v2.7 level 3 global-scale grid averaged $\left(0.5^{\circ} \times\right.$ $\left.0.5^{\circ}\right)$ SIF retrieve dataset from the Global Ozone Monitoring
Instrument - 2 (GOME-2), which taken from the Aura Validation Data Centre (AVDC) data archive (avdc.gsfc.nasa.gov)(Joiner et al. 2014). GOME-2 SIF retrievals are derived from the filling-in of solar Fraunhofer lines in the vicinity of the $740 \mathrm{~nm}$ far-red chlorophyll fluorescence emission peak (Joiner et al. 2013). In this study, we used monthly data covers the $2007-2013$ time period to analyse the relationship between SIF and GPP.

\subsection{MPI GPP}

Monthly GPP estimates is used at $0.5^{\circ}$ scale from the Max Planck Institute (MPI) for Biogeochemistry(www.bgcjena.mpg.de/geodb/projects/Data.php)(Jung et al. 2011).The MPI GPP product is a statistical data driven model, which simulated ecosystem-level GPP relatively well documented by many articles. The MPI GPP data set used in this study covers the $2007-2013$ time period.

\subsection{Temperature}

WorldClim v2 average monthly temperature data is used from 1970 - 2000 (worldclim.org)(Fick and Hijmans 2017), and we averaged monthly data to get the annual average temperature data. The spatial resolution of temperature data is resampled to $0.5^{\circ}$ grid with the nearest neighbour method in matlab. We divide the annual average temperature into four levels $\left(<-5^{\circ} \mathrm{C}\right.$, $5{ }^{\circ} \mathrm{C} \sim 5^{\circ} \mathrm{C}, 5{ }^{\circ} \mathrm{C} \sim 15^{\circ} \mathrm{C},>15^{\circ} \mathrm{C}$ ) to analyse the influence of temperature on GPP estimation.

\subsection{Precipitation}

Precipitation data is ESRL PSD Long term monthly means V4.01 global gridded data $\left(0.5^{\circ} \times 0.5^{\circ}\right)$ from $1981-2010$ from esrl.noaa.gov(Willmott and Matsuura 2001), and we totalled monthly data to get the annual total precipitation data. We divide the annual total precipitation into four levels according

\footnotetext{
* Corresponding author
} 
to criteria for the division of dry and wet areas in China, that are $<200 \mathrm{~mm}, 200 \mathrm{~mm} 400 \mathrm{~mm}, 400 \mathrm{~mm} \sim 800 \mathrm{~mm}$, $>800 \mathrm{~mm}$.

\subsection{Analysis}

The study area was identified as China, so the above data is only selected in China and processed in matlab. SIF and corresponding GPP monthly data $(n=84)$ are taken out depending on the four temperature grades respectively. Then simple linear regression analysis was performed on above four sets of data in matlab, and we could obtain determination coefficient $\left(\mathrm{R}^{2}\right)$ to show the relationship between SIF and GPP. The same operation had been done in the annual total precipitation data set.

\section{RESULTS AND DISCUSSION}

The results (Figure 1) showed that $\mathrm{R}^{2}>0.6$, when the annual average temperature ranges from $-5^{\circ} \mathrm{C}$ to $15^{\circ} \mathrm{C}$, the best linear fit is the temperature range of $-5^{\circ} \mathrm{C} \sim 5^{\circ} \mathrm{C}\left(\mathrm{R}^{2}=0.77\right)$. The lowest $\mathrm{R}^{2}$ is when the annual average temperature is lower than $-5^{\circ} \mathrm{C}$ $\left(\mathrm{R}^{2}=0.40\right)$, it might be because the temperature is so cold that vegetation is extremely sparse. When we thought $R^{2}$ is greater than 0.6, it indicated that SIF is optimal for GPP estimation. Therefore, we could believe that SIF is a good indicator for GPP, when the average annual temperature is at $-5^{\circ} \mathrm{C} \sim 15^{\circ} \mathrm{C}$.

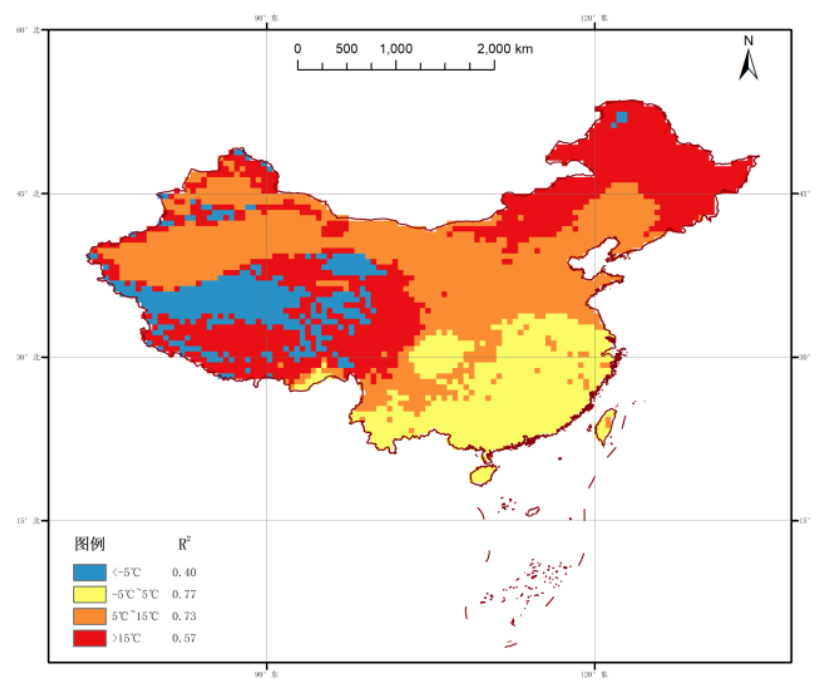

Figure 1. The relationship between SIF and GPP is analysed in four levels of annual average temperature used simple linear regression analysis.

As shown in Figure 2 implicated that $\mathrm{R}^{2}>0.6$, when the annual total precipitation ranges higher than $200 \mathrm{~mm}$, the best linear fit is the precipitation range of $400 \mathrm{~mm} \sim 800 \mathrm{~mm}$ $\left(\mathrm{R}^{2}=0.77\right)$. The lowest $\mathrm{R}^{2}$ is when the annual total precipitation is lower than $200 \mathrm{~mm}\left(\mathrm{R}^{2}=0.17\right)$, it was possible that the precipitation is so rare that vegetation is extremely sparse. If we thought $R^{2}$ is greater than 0.6, it indicated that SIF is optimal for GPP estimation. Hence, we could believe that SIF is a good indicator for GPP, when the average annual precipitation is higher than $200 \mathrm{~mm}$.

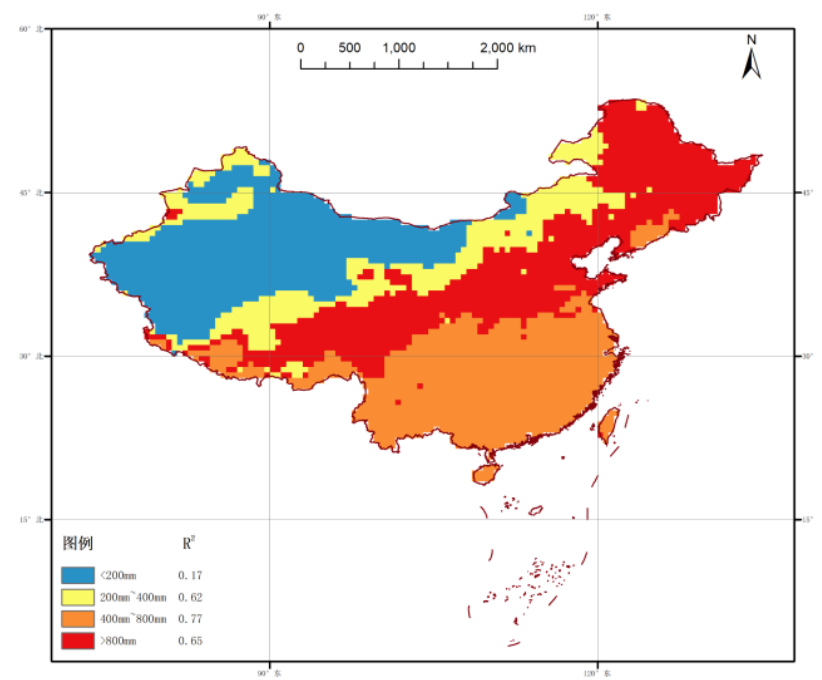

Figure 2. The relationship between SIF and GPP is analysed in four levels of annual total precipitation used simple linear regression analysis.

From the above, we could safely conclude that we can estimate global GPP using the SIF dataset, when the annual average temperature in the range of $-5^{\circ} \mathrm{C} \sim 15^{\circ} \mathrm{C}$, meanwhile, the annual total precipitation in the range higher than $200 \mathrm{~mm}$.

\section{CONCLUSION}

In this study, we analysed the relationship between SIF and GPP in different levels of annual average temperature and annual total precipitation respectively. We concluded that SIF is the optimal method to estimate GPP, when the annual average temperature in the range of $-5^{\circ} \mathrm{C} \sim 15^{\circ} \mathrm{C}$ and the annual total precipitation in the range higher than $200 \mathrm{~mm}$.

With the development of the spectroscopy sensor, we will get more and more subtle spatial resolution, i.e. FLEX, so that we can get more accurate conclusions.

\section{ACKNOWLEDGEMENTS (OPTIONAL)}

This work was supported by the National Key Research and Development Project [2016YFA0602301], the Jilin Provincial Science \& Technology Development Project [20180101313JC] and the National Natural Science Foundation of China [41001258, 41671347].

\section{REFERENCES}

Damm, A., Elbers, J., Erler, A., Gioli, B., Hamdi, K., Hutjes, R., Kosvancova, M., Meroni, M., Miglietta, F., Moersch, A., Moreno, J., Schickling, A., Sonnenschein, R., Udelhoven, T., Van Der Linden, S., Hostert, P. and Rascher, U., 2010. Remote sensing of sun-induced fluorescence to improve modeling of diurnal courses of gross primary production (GPP). Global Change Biology, 16, pp. 171-186

Fick, S. E. and Hijmans, R. J., 2017. WorldClim 2: new 1-km spatial resolution climate surfaces for global land areas. International Journal of Climatology, 37, pp. 4302-4315 
Frankenberg, C., Butz, A. and Toon, G. C., 2011a. Disentangling chlorophyll fluorescence from atmospheric scattering effects in O2A-band spectra of reflected sun-light. Geophysical Research Letters, 38, pp. L03801

Frankenberg, C., Fisher, J. B., Worden, J., Badgley, G., Saatchi, S. S., Lee, J.-E., Toon, G. C., Butz, A., Jung, M., Kuze, A. and Yokota, T., 2011b. New global observations of the terrestrial carbon cycle from GOSAT: Patterns of plant fluorescence with gross primary productivity. Geophysical Research Letters, 38, pp. L17706

Heinsch, F. A., Maosheng, Z., Running, S. W., Kimball, J. S., Nemani, R. R., Davis, K. J., Bolstad, P. V., Cook, B. D., Desai, A. R., Ricciuto, D. M., Law, B. E., Oechel, W. C., Hyojung, K. Hongyan, L., Wofsy, S. C., Dunn, A. L., Munger, J. W., Baldocchi, D. D., Liukang, X., Hollinger, D. Y., Richardson, A D., Stoy, P. C., Siqueira, M. B. S., Monson, R. K., Burns, S. P. and Flanagan, L. B., 2006. Evaluation of remote sensing based terrestrial productivity from MODIS using regional tower eddy flux network observations. IEEE Transactions on Geoscience and Remote Sensing, 44, pp. 1908-1925

Joiner, J., Guanter, L., Lindstrot, R., Voigt, M., Vasilkov, A. P., Middleton, E. M., Huemmrich, K. F., Yoshida, Y. and Frankenberg, C., 2013. Global monitoring of terrestrial chlorophyll fluorescence from moderate spectral resolution near-infrared satellite measurements: methodology, simulations, and application to GOME-2. Atmospheric Measurement Techniques Discussions, 6, pp. 3883-3930

Joiner, J., Yoshida, Y., Vasilkov, A. P., Middleton, E. M., Campbell, P. K. E., Yoshida, Y., Kuze, A. and Corp, L. A., 2012. Filling-in of near-infrared solar lines by terrestrial fluorescence and other geophysical effects: simulations and space-based observations from SCIAMACHY and GOSAT. Atmospheric Measurement Techniques, 5, pp. 809-829

Joiner, J., Yoshida, Y., Vasilkov, A. P., Schaefer, K., Jung, M., Guanter, L., Zhang, Y., Garrity, S., Middleton, E. M., Huemmrich, K. F., Gu, L. and Belelli Marchesini, L., 2014. The seasonal cycle of satellite chlorophyll fluorescence observations and its relationship to vegetation phenology and ecosystem atmosphere carbon exchange. Remote Sensing of Environment, 152, pp. 375-391

Jung, M., Reichstein, M., Margolis, H. A., Cescatti, A., Richardson, A. D., Arain, M. A., Arneth, A., Bernhofer, C., Bonal, D., Chen, J., Gianelle, D., Gobron, N., Kiely, G., Kutsch, W., Lasslop, G., Law, B. E., Lindroth, A., Merbold, L., Montagnani, L., Moors, E. J., Papale, D., Sottocornola, M., Vaccari, F. and Williams, C., 2011. Global patterns of landatmosphere fluxes of carbon dioxide, latent heat, and sensible heat derived from eddy covariance, satellite, and meteorological observations. Journal of Geophysical Research, 116, pp. G00J07

Parazoo, N. C., Bowman, K., Fisher, J. B., Frankenberg, C., Jones, D. B., Cescatti, A., Perez-Priego, O., Wohlfahrt, G. and Montagnani, L., 2014. Terrestrial gross primary production inferred from satellite fluorescence and vegetation models. Glob Chang Biol, 20, pp. 3103-3121
Sun, Y., Frankenberg, C., Wood, J. D., Schimel, D. S., Jung, M., Guanter, L., Drewry, D. T., Verma, M., Porcar-Castell, A., Griffis, T. J., Gu, L., Magney, T. S., Köhler, P., Evans, B. and Yuen, K., 2017. OCO-2 advances photosynthesis observation from space via solarinduced chlorophyll fluorescence. Science, 358, pp. eaam5747

Willmott, C. J. and Matsuura, K., 2001. Terrestrial Air Temperature and Precipitation: Monthly and Annual Time Series (1950-1999). http://climate.geog.udel.edu/ climate/html_pages/README.gh cn_ts2.html.

Zhang, Y., Guanter, L., Berry, J. A., Joiner, J., van der Tol, C., Huete, A., Gitelson, A., Voigt, M. and Kohler, P., 2014. Estimation of vegetation photosynthetic capacity from spacebased measurements of chlorophyll fluorescence for terrestrial biosphere models. Glob Chang Biol, 20, pp. 3727-3742 